Elsevier

\title{
Acetylcholine, carbachol, and GABA induce no detectable change in the length of isolated outer hair cells
}

\author{
Richard P. Bobbin ${ }^{1}$, Maureen Fallon ${ }^{1}$, Jean-Luc Puel ${ }^{1}$, Georgia Bryant ${ }^{1}$, \\ Sanford C. Bledsoe, Jr. ${ }^{2}$, Gary Zajic ${ }^{2}$ and Jochen Schacht ${ }^{2}$ \\ 'Louisiana State University Medical School, Kresge Hearing Research Laboratory of the South, Department of Otolaryngology \\ and Biocommunication, New Orleans, Lousiana, U.S.A. and ${ }^{2}$ Kresge Hearing Research Institute, The University of Michigan, \\ Department of Otolaryngology, Ann Arbor, Michigan, U.S.A.
}

(Received 30 October 1989; accepted 21 February 1990)

\begin{abstract}
The mechanical and electrical properties of cochlear outer hair cells (OHCs) are suggested to modulate transduction by inner hair cells. These properties of OHCs are presumahly regulated hy efferent neurons which use several transmitters including acetylcholine (Ach) and gamma aminobutyric acid (GABA). Since it had been suggested that Ach causes isolated OHCs to shorten visibly, this study was designed to investigate whether GABA also alters the length of OHCs. OHCs were isolated from the guinea pig cochlea by mechanical dispersion after collagenase treatment. Cells were initially selected by strict morphological criteria. In addition they were only included in further studies if they attained a constant length during 10 min of superfusion with buffer solution. Neither GABA $(20 \mu \mathrm{M} ; 100 \mu \mathrm{M})$, Ach $(5 \mathrm{mM} ; 10 \mu \mathrm{M}$ with $10 \mu \mathrm{M}$ eserine) or carbachol $(10 \mu \mathrm{M} ; 100 \mu \mathrm{M})$ altered OIIC length when applied in iso-osmotic Hank's balanced salt solution (total number of cells tested, 72). If a change in length occurred it must have been smaller than $0.3 \mu \mathrm{m}$, our detection ability. In contrast. high potassium and variations in osmolarity changed hair cell length by $3-10 \%$ in agreement with other reports.
\end{abstract}

Hair cells, outer; Gamma aminobutyric acid; Acetylcholine; Shorten; Motility

\section{Introduction}

Isolated OHCs have recently been studied in vitro where they have been shown to change length with slow time constants in the msec range in response to chemical and physical stimuli (Goldstein and Mizukoshi, 1967: Zenner et al., 1985a,b; Brownell 1984; Brownell et al., 1985; Zenner, 1986a,b, 1988; Schacht and Zenner, 1987; Dulon et al., 1987, 1988) and with faster time constants in the $\mu \mathrm{s}$ range in response to electrical stimuli (Brownell, 1983, 1984; Brownell et al., 1985; Kachar et al., 1986; Ashmore, 1987). This prop-

Correspondence to: Richard P. Bobbin, Louisiana State University Medical School, Kresge Hearing Research Laboratory of the South, Department of Otolaryngology and Biocommunication, 2020 Gravier Street, Suite A, New Orleans, LA 701122234, U.S.A erty of the $\mathrm{OHCs}$ has been used to explain their modulatory role in transduction and the extreme sensitivity to sound energy of the mammalian cochlea. Now most models of cochlear function propose a role for the OHCs and their motility in a cochlear amplifier model (Davis, 1983), a negative damping model (Mountain. 1986) or other models (Dallos, 1985; Kim, 1986; Allen, 1988).

Efferent nerve fibers of the olivocochlear bundle (OCB) synapse on the OHCs. The mechanism whereby these efferent nerve fibers modulate the afferent output of the cochlea is unknown. Wiederhold (1986) states in a recent review of the role of the efferents, "Thus,... the most parsimonious explanation of efferent suppression of neural responses is that medial OCB activation changes the mechanical properties of the $\mathrm{OHCs}$ and/or their stereocilia, which changes the mechanical coupling of basilar membrane displacement to IHC [inner hair cell] stereocilia deflection.' 
Since 1978 investigators have speculated that efferent neurons innervating the $\mathrm{OHCs}$ change the length of the OHCs or the tension their stereocilia exert on the tectorial membrane (as discussed in: Bobbin and Kisiel, 1981) but it remains unknown whether the efferents actually change the length of OHCs in vivo. Brownell $(1983,1984$; Brownell et al., 1985) was the first to suggest that iontophoretically applied Ach, the neurotransmitter of the majority of the efferents, evoked a shortening of isolated OHCs. Slepecky et al. (1988b) report that they observed a shortening of OHCs greater than $1 \mu \mathrm{m}$ followed by elongation utilizing 0.5 and 5 $\mathrm{mM}$ acetylcholine applied as a solution to drops containing isolated OHCs. In addition Plinkert and Zenner (1989) in their oral presentation report that carbachol, a stable acetylcholine-like agonist, shortens isolated OHCs in about $60 \%$ of the cells observed.

While Ach is the transmitter at a majority of the efferent neurons innervating the cochlea, a subpopulation of efferents may utilize GABA as a transmitter (Altschuler and Fex, 1986). Therefore one of the purposes of this study was to test the hypothesis that GABA induces a change in the length of isolated $\mathrm{OHCs}$ in a similar fashion to that reported for Ach. In addition, we attempted to duplicate the effects on $\mathrm{OHC}$ shape of several agents studied previously by others including: hyper- and hypo-osmotic solutions, high potassium solutions, Ach, and carbachol.

\section{Methods}

Guinea pigs were anesthetized with pentobarbital (Nembutal, $30 \mathrm{mg} / \mathrm{kg}$, i.p.), decapitated, and outer hair cells isolated from the cochlea essentially as described by others (Zenner et al., 1985a, 1985b, 1988; Zajic and Schacht, 1987; Dulon et al., 1988). The bulla of both ears were removed from the animal, opened and placed in Hank's balanced salt solution at room temperature containing (mM): $\mathrm{NaCl}, 137 ; \mathrm{KCl}, 5 ; \mathrm{CaCl}_{2}, 1.2$; $\mathrm{MgCl}_{2}, \quad 0.49 ; \quad \mathrm{MgSO}_{4}, \quad 0.4 ; \quad \mathrm{KH}_{2} \mathrm{PO}_{4}, 0.44 ;$ $\mathrm{Na}_{2} \mathrm{HPO}_{4}, 0.33 ;$ D-glucose, 5.55; HEPES, 5; the pH was adjusted to 7.4 with $4 \mathrm{~N} \mathrm{NaOH}$; HBS; Gibco Labs). The osmotic pressure of the HBS was measured with a vapor pressure osmometer (Wescor). The unadjusted osmotic pressure was about $280 \mathrm{mOs}$ and $4 \mathrm{M} \mathrm{NaCl}$ was added until the desired pressure was obtained (usually $304 \mathrm{mOs}$ ).

The modiolus including turns 3 and 4 of the organ of Corti from both ears was removed and transferred to a drop $(100 \mu l)$ of HBS containing collagenase (Sigma Type IV; $1 \mathrm{mg} / \mathrm{ml}$ ) for 10 $\min$. Subsequent dissection was carried out in HBS by micromanipulation in the absence of proteolytic enzyme which had been removed by rinsing the tissue. The cells were loosened from the tissue by blunt dissection and individual cells (approximately ten) were transferred with a microliter syringe to individual drops $(100 \mu 1)$ of HBS in a Falcon dish (Becton Dickenson Labware). The dish was situated on the inverted microscope stage (Nikon Diaphot with Hoffman modulation contrast optics and bright field illumination at 40X) and cells were selected for observation that met criteria established previously for viable cells (Zajic and Schacht, 1987). These included: (1) a cylindrical shape; (2) no swelling of the cell membrane; (3) a nucleus positioned at the base of the cell; (4) no Brownian motion of the organelles. Only cells meeting these criteria were used in the studies.

One cell in each drop was selected for continued observation and measurement. A VHS recorder connected to a video camera attached to the microscope recorded the entire experimental sequence. The drop was perfused with HBS at the rate of $100 \mu \mathrm{l} / \mathrm{min}$ utilizing a peristaltic pump and glass infusion and withdrawal pipettes placed in the drop. After $5 \mathrm{~min}$ of perfusion, test solutions (TSO; i.e., Hank's containing chemicals such as $\mathrm{Ach}$ ) were introduced into the infusion tubing by placing it into TSO for $2 \mathrm{~min}$, and then returning the tubing to HBS. The delay for delivery of the TSO to the drop was $5 \mathrm{~min}$ which allowed a total of approximately $10 \mathrm{~min}$ of observation and measurement of cell length before the TSO arrived at the cell and 2 min during the exposure to TSO. Recovery from any TSO effects to this first TSO exposure was monitored by maintaining the perfusion with HBS for an additional $10 \mathrm{~min}$. In addition, all cells were tested at the end of the experiment with a second exposure to a TSO of trypan blue $(0.2 \%$, at $\min 20$ to end) or to a $2 \mathrm{~min}$ exposure to a TSO of hypo-osmotic composition ( $\min 22$ to 24 ). If a cell did not exclude the dye or did not respond with a length change to the 
hypo-osmotic TSO it was excluded from the study. All experiments were carried out at room temperature.

The drugs used as freshly prepared solutions with the $\mathrm{pH}$ adjusted when necessary were: acetylcholine chloride (Ach; Sigma), alpha-ketoglutaric acid (AKG: Sigma), eserine hemisulfate (physostigmine, Sigma), gamma-aminobutyric acid (GABA, Sigma), and carbamylcholine chloride (carbachol; Sigma). In the high potassium solutions (modified Hanks) $\mathrm{NaCl}$ was replaced by 50 and $100 \mathrm{mM} \mathrm{KCl}$, respectively.

Computer hardware (Data Translation DT 2853) and software (DT-IRIS) was used to measure the cells (in pixel length calibrated with a stage micrometer) from single frames of the VHS at one $\min (\min 1-10$ and $\min 12-26$ ) or $30 \mathrm{sec}$ (min 10-12) time intervals.

Calibration was performed with a calibrated slide, measuring the distances on the slide with the computer from a video tape of the slide. The smallest incremental distance resolved by the measuring system was $0.3 \mu \mathrm{m}$. Graphs of the length of the cell over the time span of the experiment were constructed. Then three raters independently judged the graphs as to whether a cell length change occurred and in what direction it occurred. Where they did not agree a consensual agreement was made.

\section{TABLE I}

THE NUMBER OF CELLS STUDIED AND THEIR RESPONSES TO THE APPLICATION OF TEST SOLUTIONS (TSO) OF HYPO-OSMOTIC, HYPEROSMOTIC, AND ISO-OSMOTIC HBS APPLIED TO CELLS BEING BATHED BY A HBS OF $304 \mathrm{mOs}$

\begin{tabular}{lllll}
\hline Conditions & $\begin{array}{l}\text { Con- } \\
\text { trac- } \\
\text { tion }\end{array}$ & $\begin{array}{l}\text { Elon- } \\
\text { gation }\end{array}$ & $\begin{array}{l}\text { No } \\
\text { change }\end{array}$ & $\begin{array}{l}\text { Un- } \\
\text { stable }\end{array}$ \\
\hline $\begin{array}{l}\text { hypo-osmotic } \\
304 \text { to 280 mOs: }\end{array}$ & 9 & 0 & 1 & 2 \\
$\begin{array}{l}\text { hyper-osmotic } \\
304 \text { to 330 mOs: }\end{array}$ & 0 & 4 & 4 & 1 \\
$\begin{array}{l}\text { iso-osmotic } \\
304 \text { to } 304 \text { mOs: }\end{array}$ & 0 & 0 & 10 & 4 \\
\hline
\end{tabular}

\section{Results}

We studied only cells initially meeting the appearance criteria described by others (Zajic and Schacht, 1987). Some cells changed length during the first perfusion of the drop with HBS so that

TABLE II

THE NUMBER OF CELLS STUDIED AND THEIR RESPONSES TO THE APPLICATION OF TEST SOLUTIONS (TSO) OF HYPEROSMOTIC AND ISO-OSMOTIC $5 \mathrm{mM}$ ACH APPLIED TO CELLS BEING BATHED BY HBS OF DIFFERING OSMOTIC PRESSURES

\begin{tabular}{lllll}
\hline Conditions & $\begin{array}{l}\text { Con- } \\
\text { trac- } \\
\text { tion }\end{array}$ & $\begin{array}{l}\text { Elon- } \\
\text { gation }\end{array}$ & $\begin{array}{l}\text { No } \\
\text { change }\end{array}$ & $\begin{array}{l}\text { Un- } \\
\text { stable }\end{array}$ \\
\hline $\begin{array}{l}\text { TSO }=5 \text { mM ACH } \\
314 \text { mOs to } \\
\text { HBS }=304 \text { mOs }\end{array}$ & 0 & 7 & 2 & 1 \\
TSO $=5$ mM ACH & & & & \\
300 mOs to & & 6 & 0 & 1 \\
HBS $=290$ mOs & 0 & 6 & & \\
TSO $=5$ mM ACH & & & 0 & 0 \\
324 mOs to & & 5 & & \\
HBS $=314$ mOs & 0 & 5 & & \\
$\begin{array}{l}\text { TSO }=5 \text { mM ACH } \\
304 \text { mOs to }\end{array}$ & & & & \\
HBS $=304$ mOs & 0 & 0 & & \\
\hline
\end{tabular}

TABLE III

THE NUMBER OF CELLS STUDIED AND THEIR RESPONSES TO THE APPLICATION OF TEST SOLUTIONS (TSO) OF HYPEROSMOTIC AND ISO-OSMOTIC $5 \mathrm{mM}$ AKG APPLIED TO CELLS BEING BATHED BY A HBS OF DIFFERING OSMOTIC PRESSURES

\begin{tabular}{lllll}
\hline Conditions & $\begin{array}{l}\text { Con- } \\
\text { trac- } \\
\text { tion }\end{array}$ & $\begin{array}{l}\text { Elon- } \\
\text { gation }\end{array}$ & $\begin{array}{l}\text { No } \\
\text { change }\end{array}$ & $\begin{array}{l}\text { Un- } \\
\text { stable }\end{array}$ \\
\hline $\begin{array}{l}\text { TSO }=5 \mathrm{mM} \mathrm{AKG} \\
314 \mathrm{mOs} \text { to }\end{array}$ & & & & \\
$\mathrm{HBS}=304 \mathrm{mOs}$ & 0 & 8 & 0 & 0 \\
$\begin{array}{l}\text { TSO }=5 \mathrm{mM} \text { AKG } \\
300 \mathrm{mOs} \text { to }\end{array}$ & & & & \\
$\mathrm{HBS}=290 \mathrm{mOs}$ & 0 & 5 & 2 & 0 \\
$\begin{array}{l}\text { TSO }=5 \mathrm{mM} \mathrm{AKG} \\
304 \mathrm{mOs} \text { to }\end{array}$ & & & & \\
$\mathrm{HBS}=304 \mathrm{mOs}$ & 0 & 0 & 13 & 2 \\
\hline
\end{tabular}




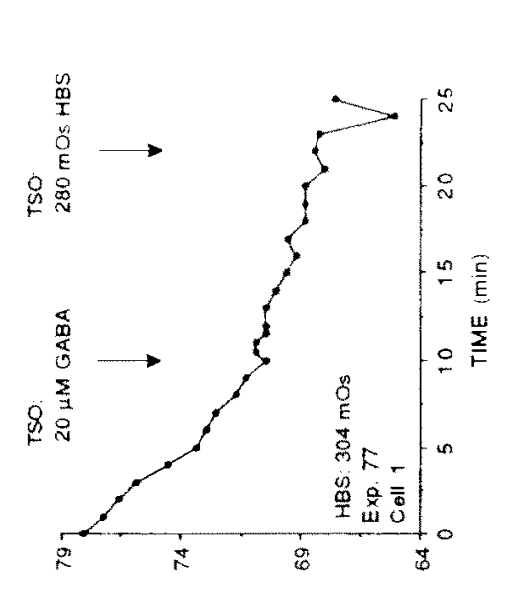

(แกi) HIONヨา Tาวอ

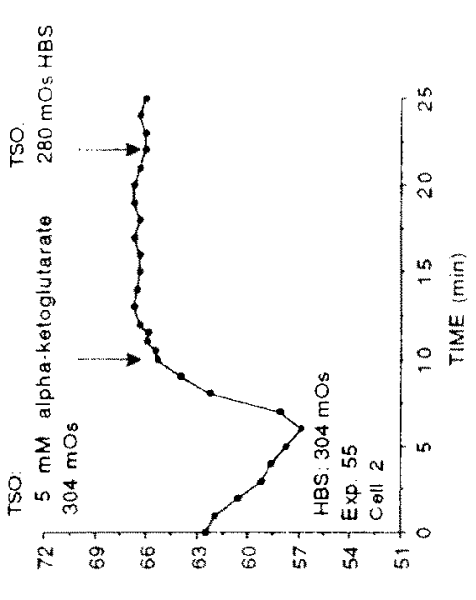

(แบi) HLSN3า Tีอ

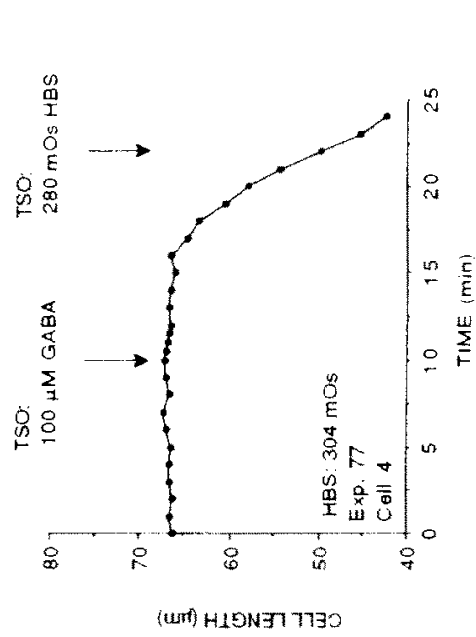

$\overline{\mathrm{s}}$

要要要

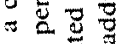

车些

5 过

的

है

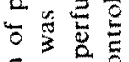

틀

$03 \frac{3}{5}$

\&

ป

$<\frac{3}{3}$

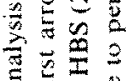

$= \pm$

导

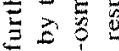

$\Xi 8$

㱐远

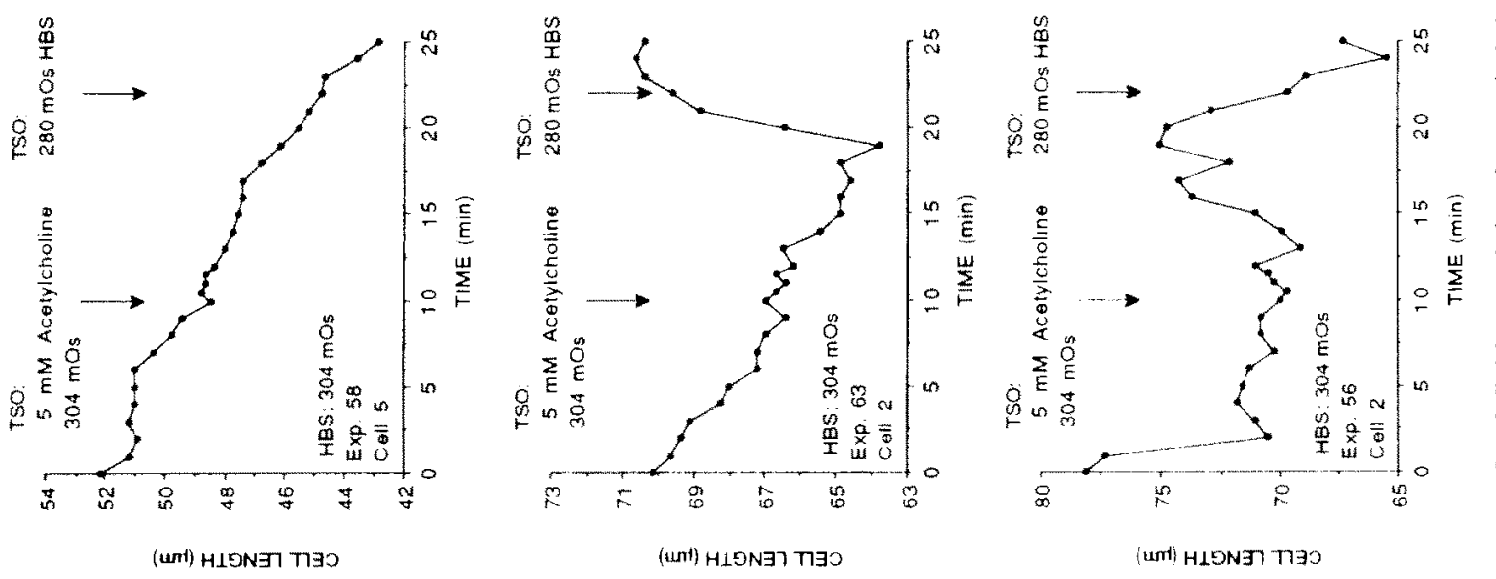

光

象

린

플 震官

चल

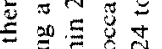

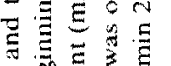

-

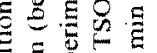

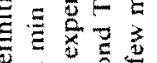

प

$5 \pm \pm$

×

这焉

닌

एव

3ิ

$\exists$ 正

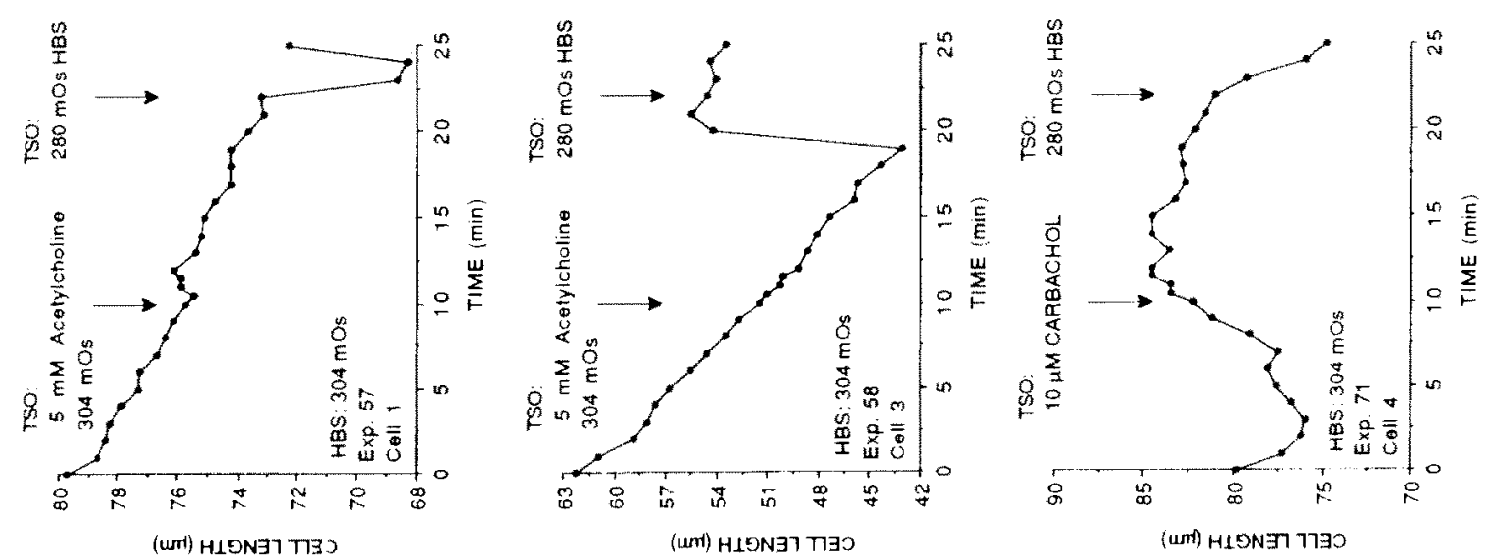

$=\frac{4}{3}$

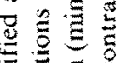

㐘

品

슬을

可范

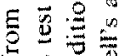

头㝵

क월

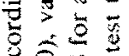

总家的

$\approx 0$ 일

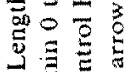

$\therefore 8$

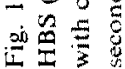



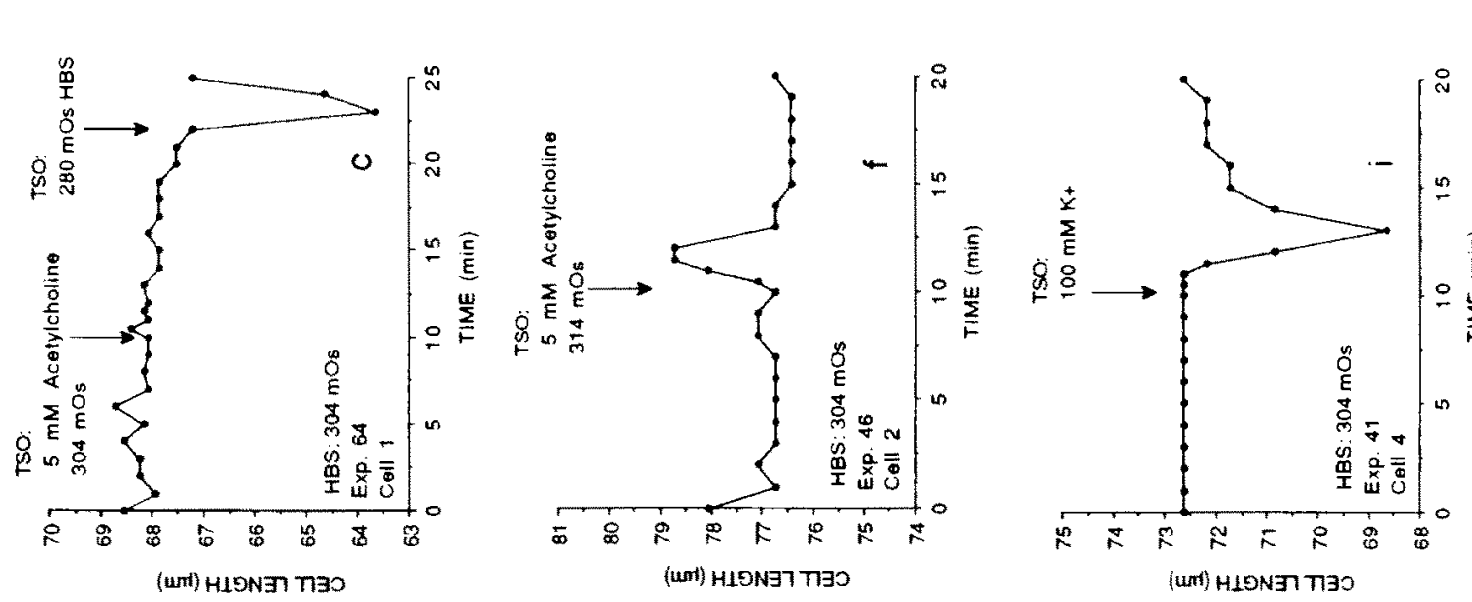

E

两

용

을

$=\frac{ \pm}{\sigma}$

를

㱐

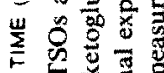

क

을 흥 홍

施

的政政

$\ddot{0} \pm$

㱐

용요

प्रू...
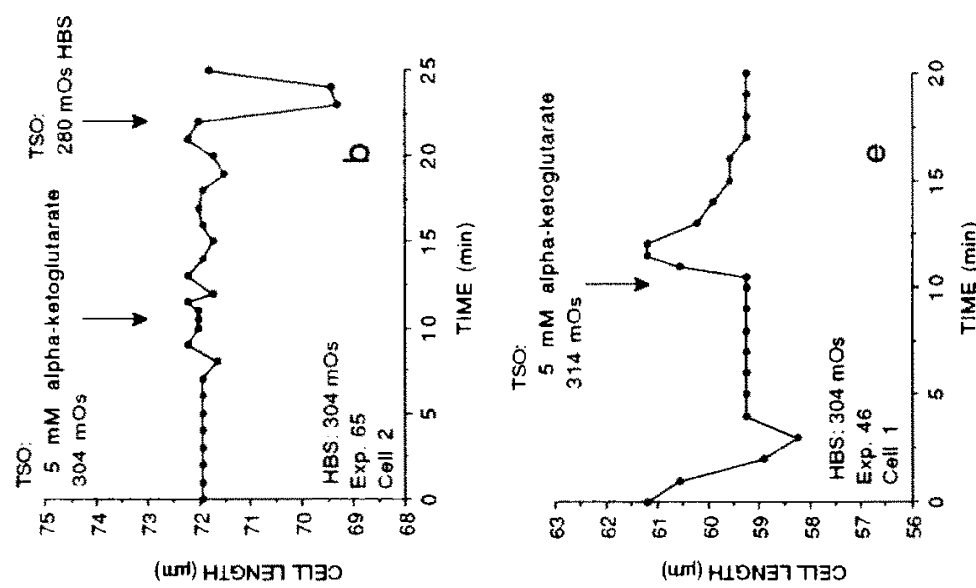

总过

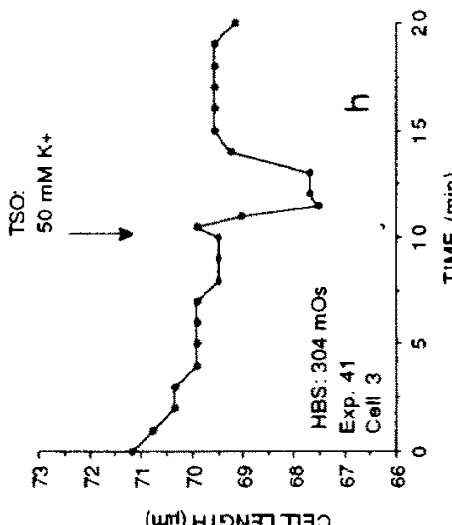

응

응

응

范些

$5 \stackrel{5}{0}$

Е 总焉

○ิํㅗㄹ 突

용용

总㤩焉

눙요

荡可

$\infty$ 这菏

窇焉

$\overrightarrow{3}$

害 $\mathrm{E}$

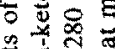
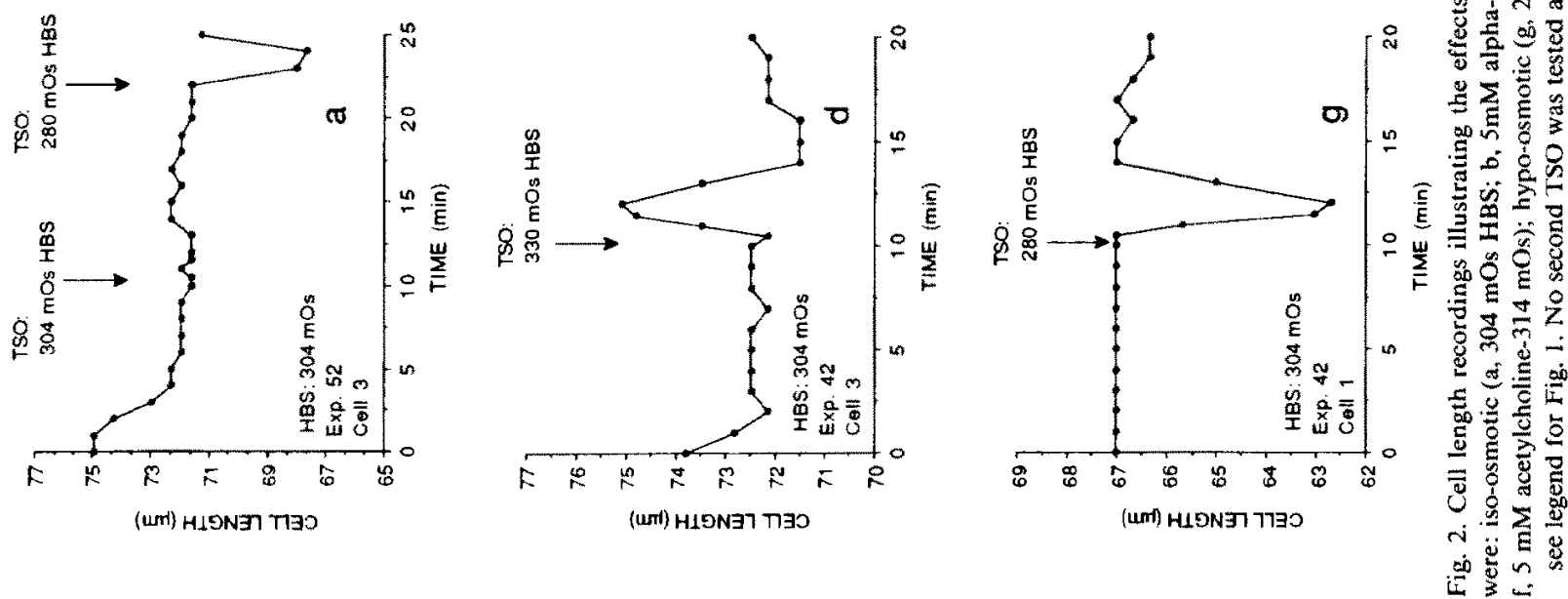
additional criteria had to be developed. A change in length during the initial few min of HBS perfusion which we attributed to a stabilization process was acceptable. However, the cell had to achieve a constant length before application of the TSO. In addition, some cells changed length at a time when it could not be attributed to the TSO in the drop. Therefore, a criterion was added which stated that cells which underwent length changes that did not occur during the TSO or soon after were also classified as unstable. Fig. 1 illustrates recordings from cells which were judged as not meeting this "stability" criterion. One of the cells measured (Fig. 1, Exp 58, Cell 3) slowly shortened, then at min 19 the cell suddenly elongated. This is an example of a shape change which could not be attributed to the application of TSO. This particular cell extruded cytoplasm from just below the cuticular plate at min 19 and did not respond to the internal control of hypotonic TSO.

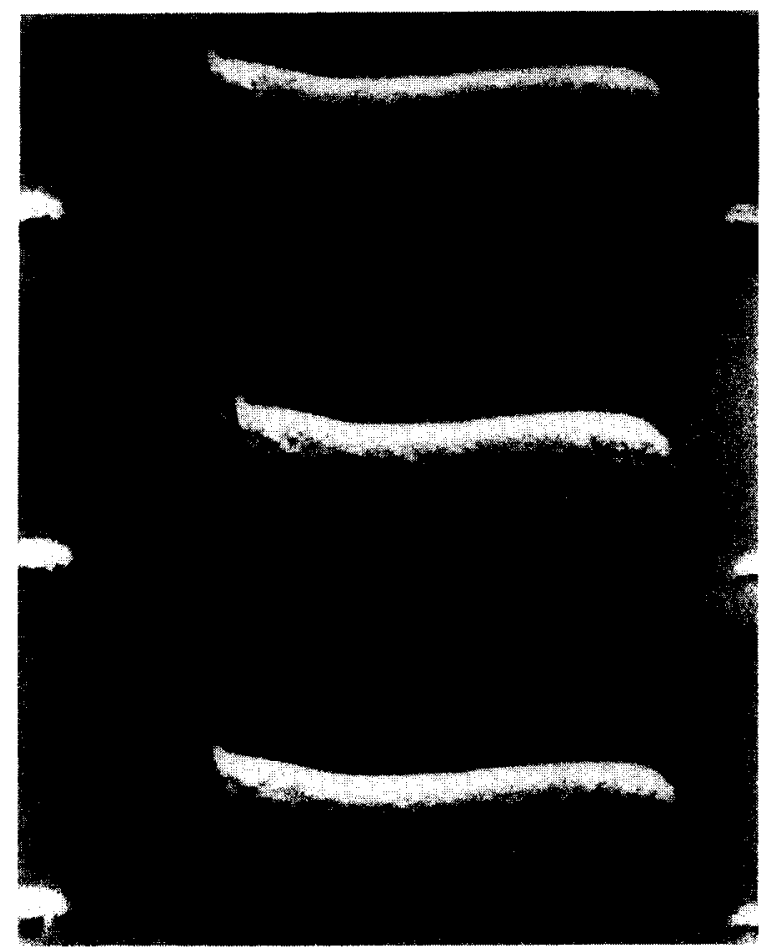

Fig. 3. Example of an $\mathrm{OHC}$ shortening to the application of a TSO of $50 \mathrm{mM}$ potassium. Pictures are taken before (bottom), during (middle), and after (top) the application of $50 \mathrm{mM}$ potassium as described in Fig. 2.
TABLE IV

THE NUMBER OF CELLS STUDIED AND THEIR RESPONSES TO THE APPLICATION OF TEST SOLUTIONS (TSO) OF $10 \mu \mathrm{M}$ ACH WITH $10 \mu \mathrm{M}$ ESERINE AND 10 AND $100 \mu \mathrm{M}$ CARBACHOL APPLIED TO CELLS BEING BATHED BY A HBS OF THE SAME OSMOTIC PRESSURE (304 mOs)

\begin{tabular}{lllll}
\hline Conditions & $\begin{array}{l}\text { Con- } \\
\text { trac- } \\
\text { tion }\end{array}$ & $\begin{array}{l}\text { Elon- } \\
\text { gation }\end{array}$ & $\begin{array}{l}\text { No } \\
\text { change }\end{array}$ & $\begin{array}{l}\text { Un- } \\
\text { stable }\end{array}$ \\
\hline $\begin{array}{l}\text { TSO }=10 \mu \mathrm{M} \text { ACH } \\
\text { with } 10 \mu \mathrm{M}\end{array}$ & 0 & 0 & 10 & 7 \\
$\begin{array}{l}\text { Eserine } \\
\text { TSO }=10 \mu \mathrm{M}\end{array}$ & 0 & 0 & 9 & 2 \\
Carbachol & & & & \\
$\begin{array}{l}\text { TSO }=100 \mu \mathrm{M} \\
\text { Carbachol }\end{array}$ & 0 & 0 & 9 & 6 \\
\hline
\end{tabular}

In many cells, the start of the perfusion induced a shortening (Fig. 2a, 2d, 2e, 2f and 2h). After the cell had stabilized during the perfusion, addition of a TSO of HBS ( $304 \mathrm{mOs}$ HBS at min 10 in Fig. 2a) did not change the cell's length. A possible explanation is that the drops in the dish become hyperosmotic over time and the cells in the drop respond by slowly lengthening. When the perfusion is started the fresh HBS arriving at the drop returns the osmotic pressure of the drop to the original pressure and this, in turn, causes the cell to shorten to its original shape.

The application of hypo-osmotic solutions shortened the cells (Fig. 2g; Table I). Subsequently, the application of a hypo-osmotic solution was utilized as an internal control in several cells. For example (Fig. 2a), even though a cell

\section{TABLE $V$}

THE NUMBER OF CELLS STUDIED AND THEIR RESPONSES TO THE APPLICATION OF TEST SOLUTIONS (ISO) OF 20 AND $100 \mu \mathrm{M}$ GABA APPLIED TO CELLS BEING BATHED BY A HBS OF THE SAME OSMOTIC PRESSURE (304 mOs)

\begin{tabular}{lllll}
\hline Conditions & $\begin{array}{l}\text { Con- } \\
\text { trac- } \\
\text { tion }\end{array}$ & $\begin{array}{l}\text { Elon- } \\
\text { gation }\end{array}$ & $\begin{array}{l}\text { No } \\
\text { change }\end{array}$ & $\begin{array}{l}\text { Un- } \\
\text { stable }\end{array}$ \\
\hline TSO $=20 \mu \mathrm{M}$ GABA & 0 & 0 & 9 & 4 \\
TSO $=100 \mu \mathrm{M}$ GABA & 0 & 0 & 8 & 6 \\
\hline
\end{tabular}


(เก) HLONAา T3O
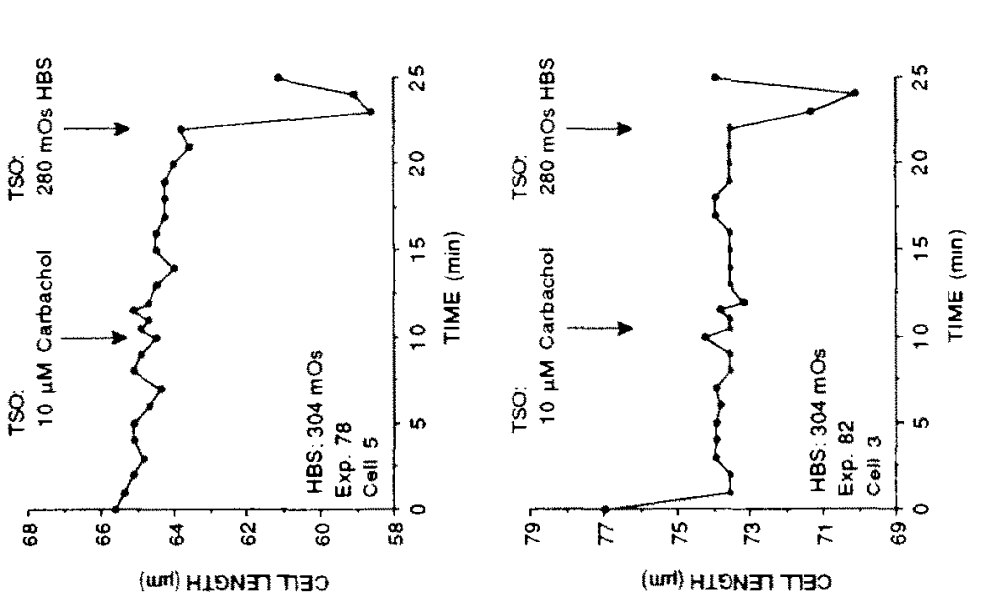

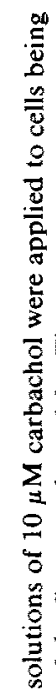
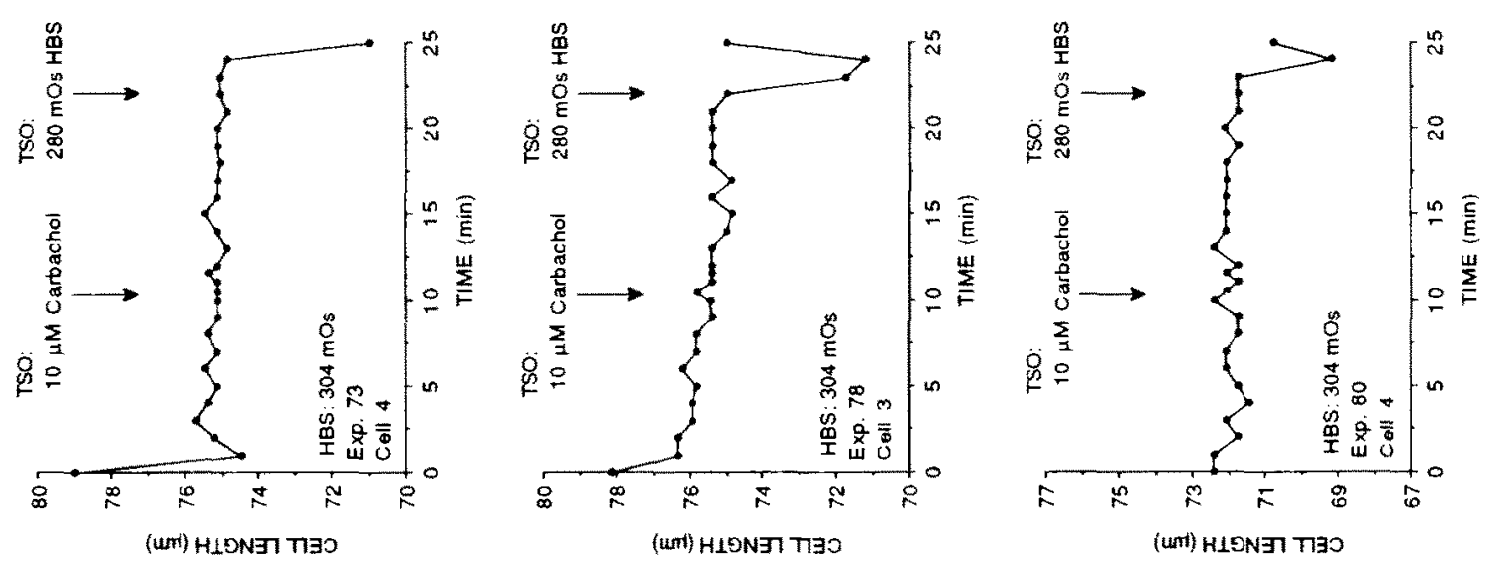

要.

웅

㯊

공

으ㅁㅗㅛ

द

क्ष

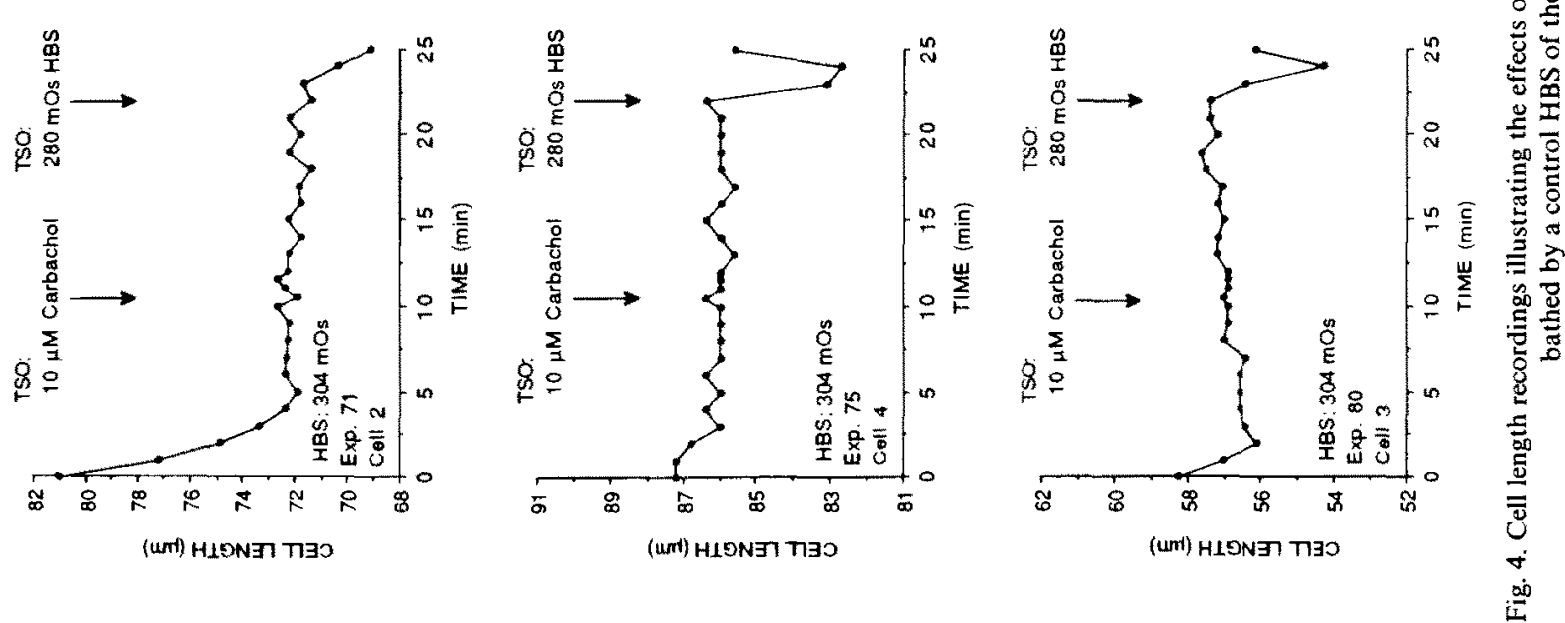




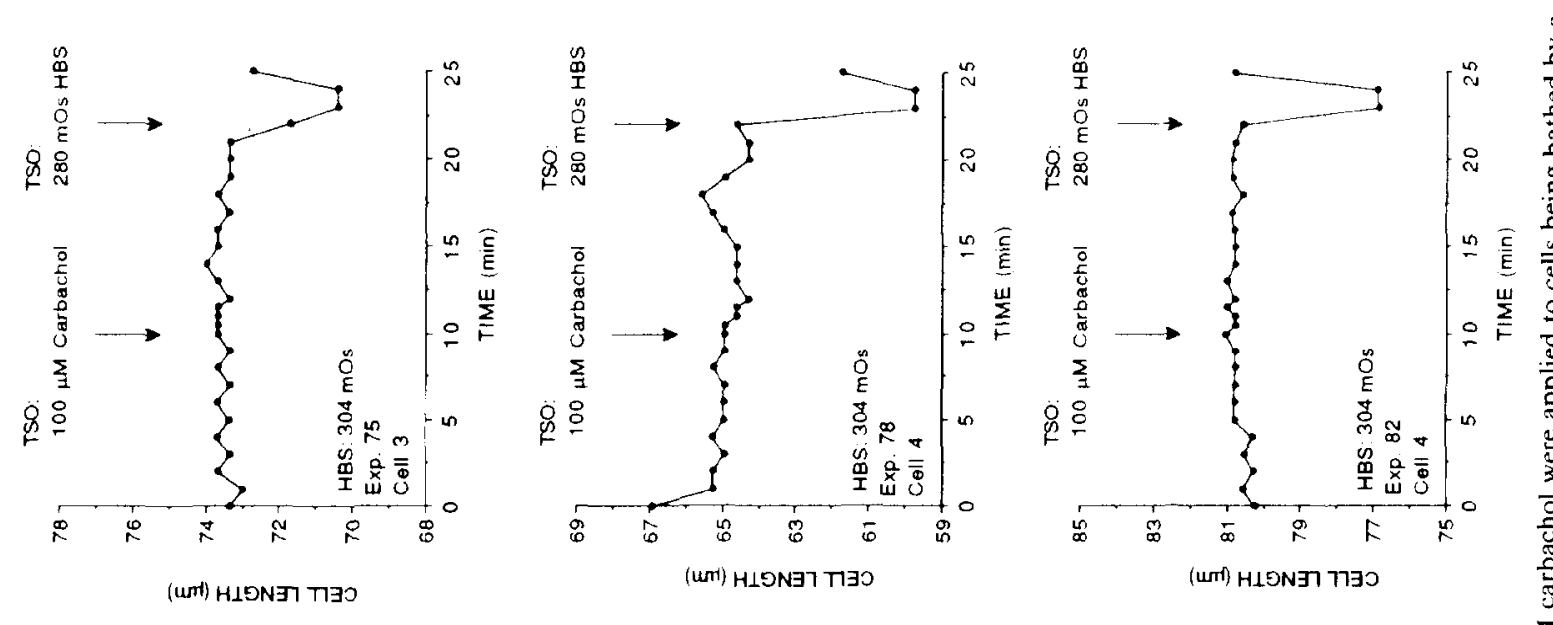

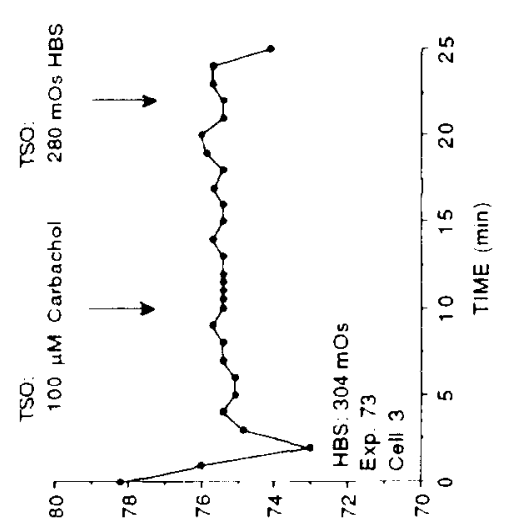

(UMI) HLONAT TIJO

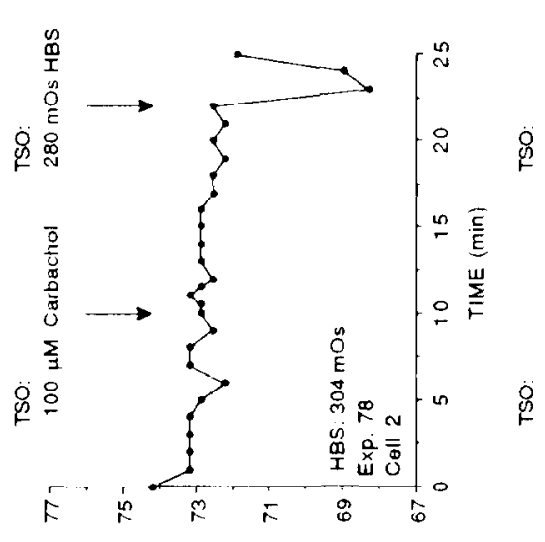

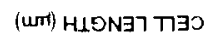

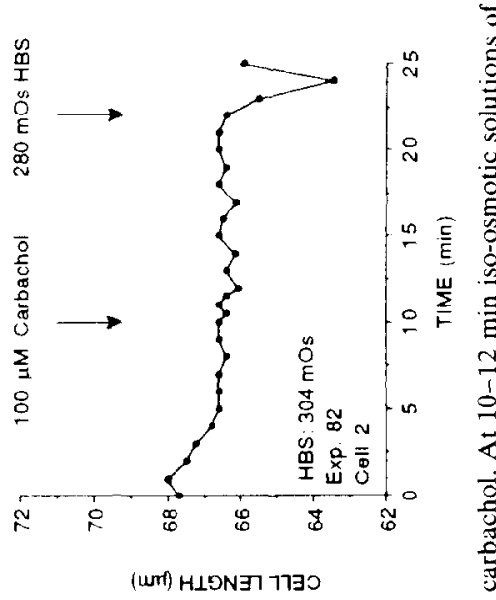

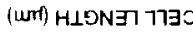

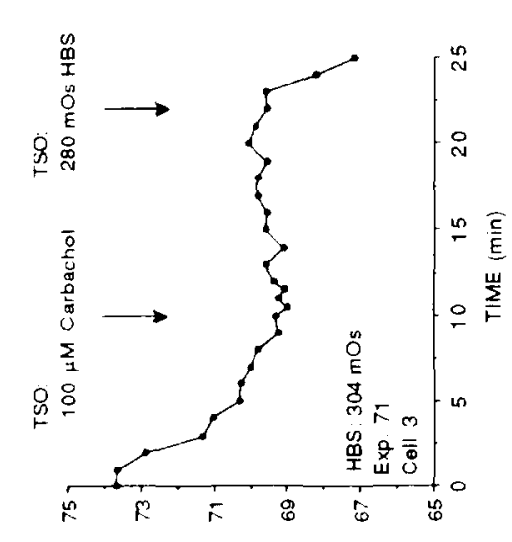

(แMI) HISNรา רา

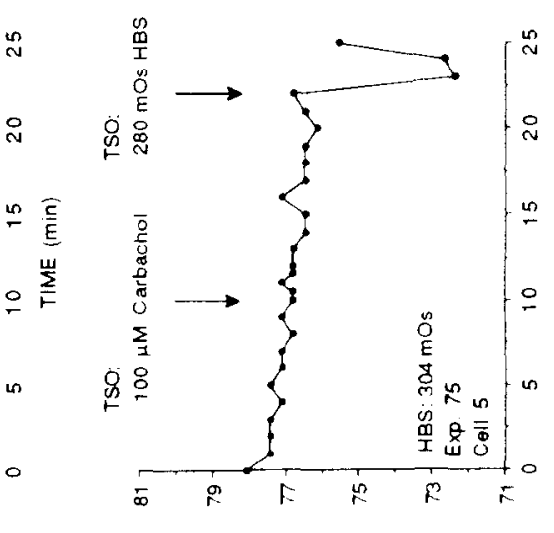

(แก) H19Nヨา TIบง

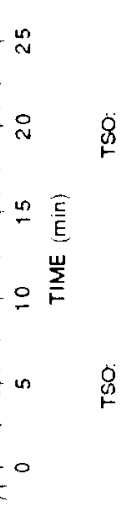

$\longrightarrow$

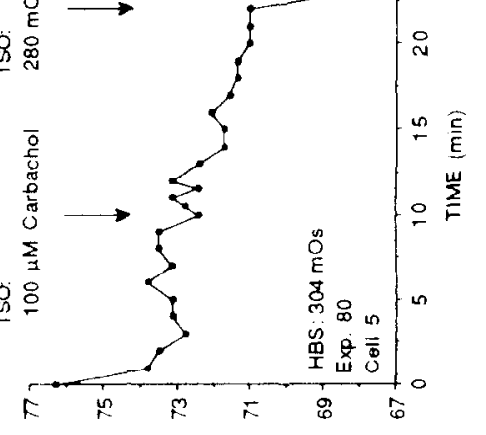

(แm) MHONヨา רา อ 

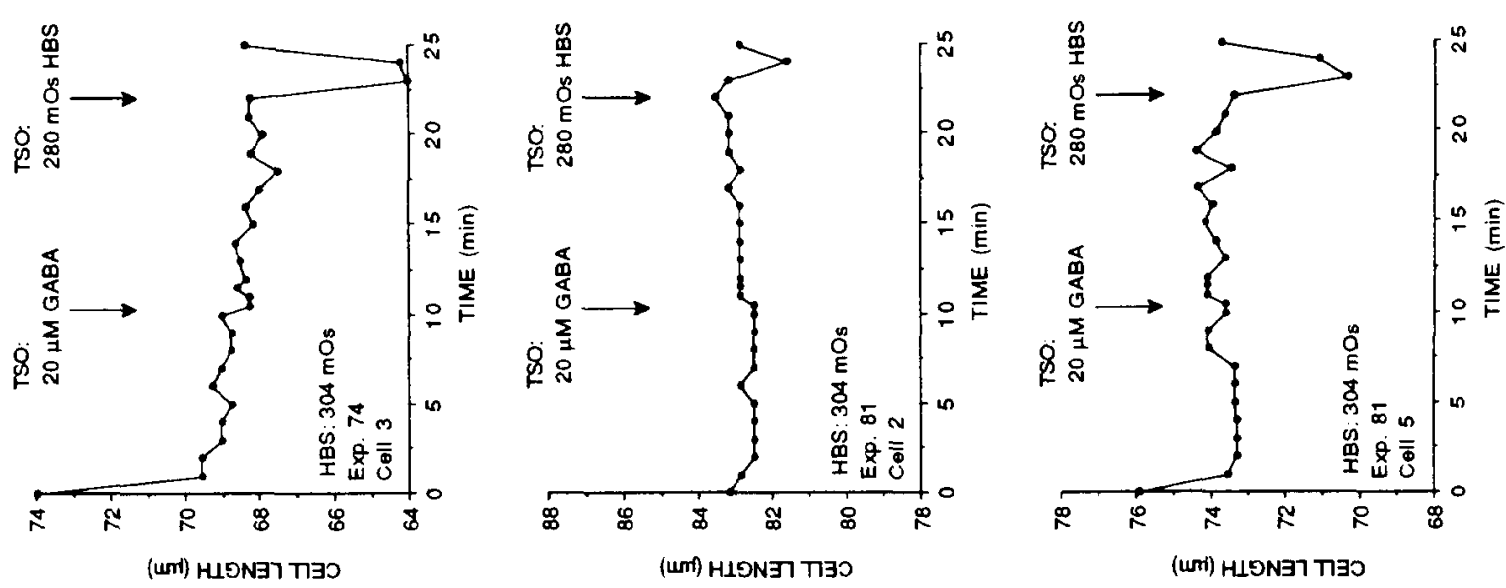

告
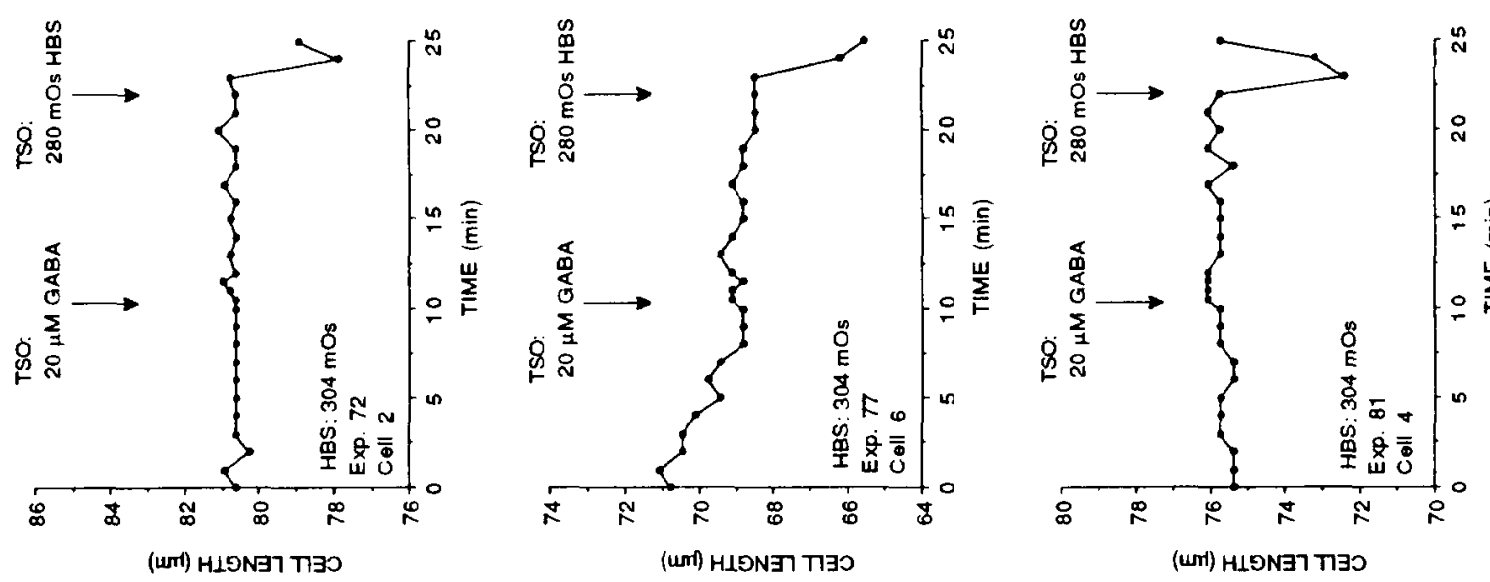

号

$$
\text { (n) }
$$




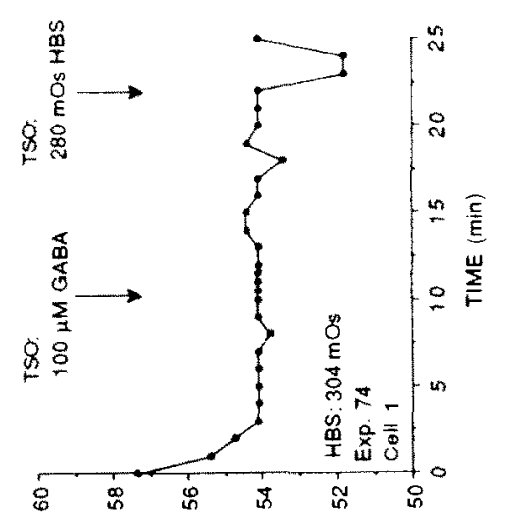

(แึ) H15N3า กีอ
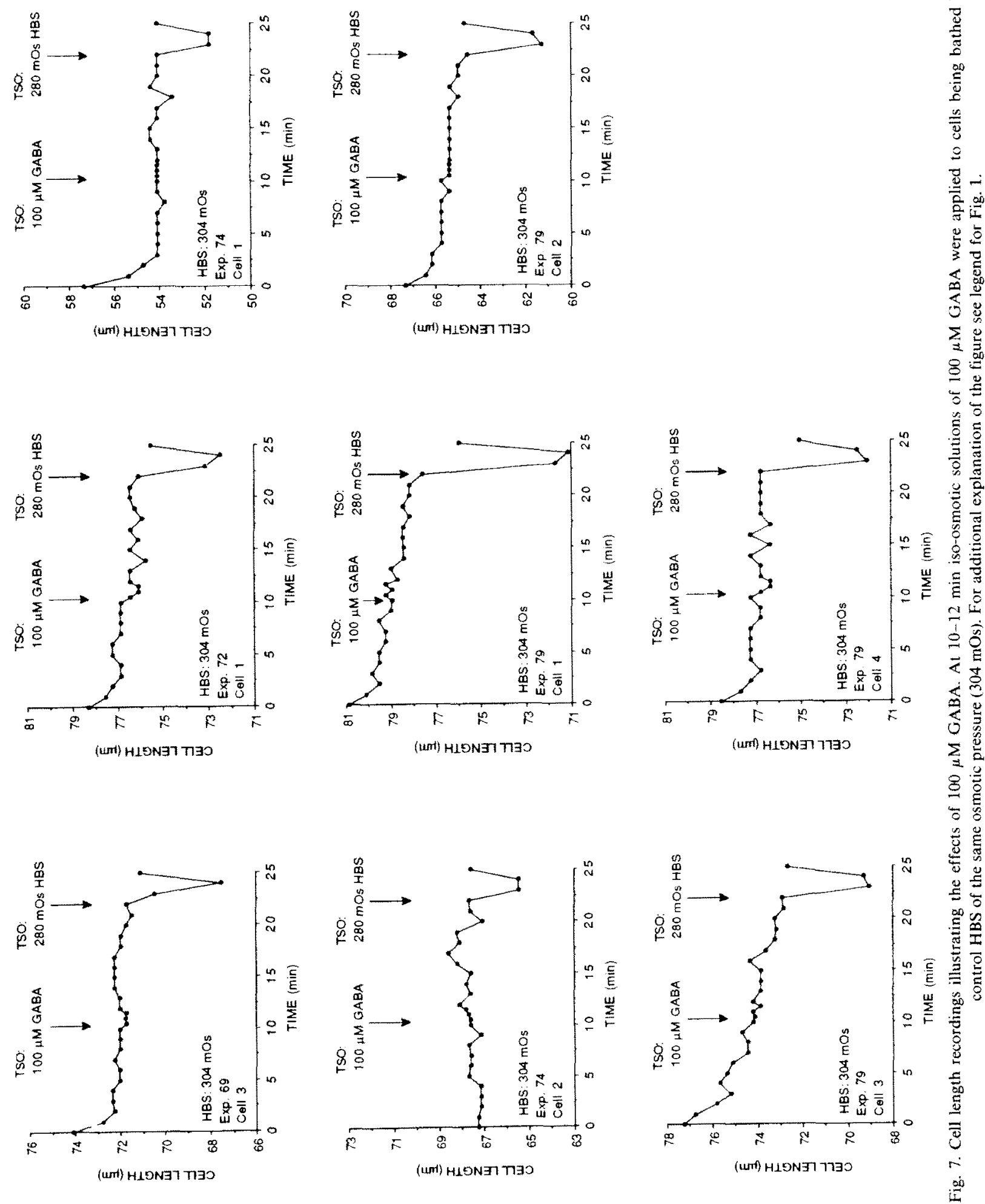
does not respond to the application of fresh TSO solution (304 mOs HBS at min 10), the cell is still able to shorten to a subsequent application of hypo-osmotic solution ( $280 \mathrm{mOs} \mathrm{HBS}$ at min 22 in Fig. 2a). Increasing the osmotic pressure elongated the cells but at a lesser incidence than decreasing the osmotic pressure (Fig. 2d; Table I). Potassium chloride ( $50 \mathrm{mM}, N=7 ; 100 \mathrm{mM}, N=7$ ) induced a reversible shortening of all OHCs tested (Fig. $2 \mathrm{~h}$ and 2i; Fig. 3).

The addition of either $5 \mathrm{mM}$ alpha-ketoglutarate (AKG) or Ach to HBS of either 290 mOs, $304 \mathrm{mOs}$ or $314 \mathrm{mOs}$ increased the osmotic pressure of the HBS by about $10 \mathrm{mOs}$. The OHCs elongated in response to $5 \mathrm{mM}$ Ach (Fig. 3f, Table II) and the elongation was duplicated by $5 \mathrm{mM}$ AKG (Fig. 3e, Table III). Experiments which applied $5 \mathrm{mM}$ Ach or AKG iso-osmotic with the isolation and perfusion medium (HBS, $304 \mathrm{mOs}$ ) did not result in a detectable change in cell length (Fig. 3b and 3c; Tables II and III).

When Ach $(10 \mu \mathrm{M})$ was applied together with eserine $(10 \mu \mathrm{M})$, a cholinesterase inhibitor, it also induced no change in cell length (Table IV). We tested carbachol, an Ach agonist that is not hydrolysed by cholinesterase. Carbachol at 10 and 100 $\mu \mathrm{M}$ did not change the length of the cells (Figs. 4 and 5, Table IV). In addition, GABA at 20 and $100 \mu \mathrm{M}$ induced no change in the cell length (Figs. 6 and 7, Table V).

\section{Discussion}

Our results clearly indicate that neither Ach (5 $\mathrm{mM}$, or $10 \mu \mathrm{M}$ with eserine $10 \mu \mathrm{M})$, carbachol (10 or $100 \mu \mathrm{M})$, nor GABA $(20$ or $100 \mu \mathrm{M})$ induced a detectable change in the length of OHCs. This is in contrast to the results obtained with high potassium and changes in osmotic pressure which consistently altered $\mathrm{OHC}$ length in agreement with the previous results of others (for example, Zenner, 1986b; Dulon et al., 1988).

At present we can only speculate as to the reasons for the absence of a change in the length of the OHCs to the neurotransmitters of the efferent nerve fibers which synapse on the OHCs. Changing the membrane potential of $\mathrm{OHCs}$ alters their lengths in vitro: an increase in the membrane potential (hyperpolarization) increases their length, whereas a decrease (depolarization) decreases their length (Brownell, 1983, 1984; Brownell et al., 1985; Ashmore, 1987; Holley and Ashmore, 1988; Zenner, et al., 1985a, 1985b; Kachar et al., 1986; Santos-Sacchi and Dilger, 1988). The OHCs undergo a $0.02-0.03 \mu \mathrm{m}$ maximal length change per $\mathrm{mV}$ change in the membrane potential (Ashmore 1987; Santos-Sacchi, 1989; Iwasa and Kachar, 1989) whereas a change in voltage near the resting membrane potential of the cell $(-70 \mathrm{mV})$ results in less of a change in cell length (Santos-Sacchi, 1989). The maximum that the endocochlear potential responds to efferent stimulation is about $5 \mathrm{mV}$ (Fex, 1966; Konishi and Slepian, 1971). This may be used cautiously as an estimate of the possible change in the hair cell potential. Under this assumption, an $\mathrm{OHC}$ membrane potential change of $5 \mathrm{mV}$ would result in a hair cell length change of $0.1-0.15 \mu \mathrm{m}$. This change is an order of magnitude less than that reported by others for the shortening due to Ach (e.g., $>1 \mu \mathrm{m}$ by Slepecky et al., 1988b). Also, it is less than the resolution of our present system $(0.3 \mu \mathrm{m})$. Thus, our negative results with length measurements are consistent with the electrophysiological data.

Several laboratories have reported that potassium shortens isolated outer hair cells (Goldstein and Mizukoshi, 1967; Brownell et al., 1985; Slepecky et al., 1988b, Zenner et al., 1988; Slepecky et al., 1988a; Dulon, et al., 1988) with no negative reports appearing in the literature. Hypo-osmotic solutions likewise shorten isolated OHCs (Dulon, et al., 1988). While some laboratories (Dulon et al., 1987; Zenner et al., 1985b) observed that OHCs elongate in response to hyperosmotic solutions, other reports (Slepecky et al., 1988a) indicate that $\mathrm{OHCs}$ do not change length, though they shrink and wrinkle, in response to hyperosmotic solutions. We studied potassium and osmotic pressure to define our preparation and to reconcile the differences others have reported.

Our results confirmed that 50 and $100 \mathrm{mM} \mathrm{KCl}$ induced a reversible shortening of the isolated $\mathrm{OHCs}$, since the effect was readily reversed by washing away the TSO of $\mathrm{KCl}$ with $\mathrm{HBS}$ after 2 min of application. We also observed a shortening of the cells in response to hypo-osmotic solutions consistent with the results of Dulon et al. (1987, 1988). The hyperosmotic solutions did induce the 
wrinkling reported by others and elongate $50 \%$ of the cells studied. This confirms the results of Zenner et al. (1985b) who found that the length change to hyperosmotic solutions was less consistent than the shortening to hypo-osmotic solutions, but is inconsistent with the lack of change in length found by others (Slepecky et al., 1988a).

There may be several reasons why our results differ from previous reports. One of the major problems with isolated $\mathrm{HC}$ work is that most investigators apply anatomical or cell appearance criteria only in selecting cells for their experiments. One of the major differences between our preparation and that of others is that we introduced the additional criterion of stability during the perfusion. Many of our cells changed length before or much later than the time when the TSO arrived at the drop. Such cells were placed in the 'unstable' category and so excluded from the study. Several cells in this category initiated a 'shortening' at the beginning of the experiment and continued to slowly shorten over time. Some of these even returned to the original length and others returned beyond the original length. If we had applied drug at the beginning of the experiment we would have attributed many of these length changes to the action of the drug with even the occurrence of recovery. This might, in part, account for the 'positive' results of others and our 'negative' results. Brownell (Brownell, 1983, 1984; Brownell et al., 1985) applied Ach by iontophoresis to isolated OHCs. He did not quantify the length change except to say it was smaller than the changes they observed in response to applied voltage gradients. According to Slepecky et al. (1988b) $5 \mathrm{mM}$ Ach applied to a drop containing the isolated OHCs shortens the cells. Neither study substantiated the observed effect as cholinergic since they did not provide pharmacological controls such as testing cholinergic agonists with much less potency (e.g., choline) or testing cholinergic antagonists against the shortening. We observed an increase in the length of our cells when duplicating their experimental design. Slepecky et al. (1988b) did not adjust the osmotic pressure of the $5 \mathrm{mM}$ Ach solution. We tested Ach $5 \mathrm{mM}$ after adding the drug to 290 mOs HBS (Slepecky et al., $1988 \mathrm{~b}$ ) as well as adding the drug to $304 \mathrm{mOs}$ HBS (the basic osmolarity in our study). Under both conditions the solutions of Ach increased the length of the OHCs. We surmise that the elongation is caused by the solutions of Ach being hyperosmotic (by $10 \mathrm{mOs}$ ) with respect to the HBS bathing the cell when the TSO is applied. Supporting this conclusion is the observation that the elongation was duplicated by $5 \mathrm{mM} \mathrm{AKG}$, a molecule which has no activity at any receptor and increased the osmotic pressure of the solution. Finally, the length change was not observed in response to TSOs of $5 \mathrm{mM}$ Ach or $5 \mathrm{mM} \mathrm{AKG}$ iso-osmotic with the HBS bathing the cells before their application. Therefore, any length changes observed under conditions of uncontrolled osmotic pressure should be considered artifacts and not cholinergic phenomena.

Ach is readily hydrolysed by cholinesterase and the absence of an effect may thus be due to its rapid breakdown. It is not known whether the enzyme is active or present in isolated OHCs. To inhibit the enzyme we tested Ach with eserine added to the solution. In these cases the cells still did not change their length. Another alternative is to test carbachol which is not hydrolysed by the esterase and yet is active at the "nicotinic-like" receptors utilized by the efferents in the guinea pig cochlea (Bobbin and Konishi, 1974). Ten and 100 $\mu \mathrm{M}$ carbachol induced no detectable change in the length of the cells. These concentrations are close to those effective in the cochlea $(50 \mu \mathrm{M}$; Bobbin and Konishi, 1974) and in the lateral line $(10 \mu \mathrm{M}$; Bobbin et al., 1985) and so should have been effective in the isolated cells. Thus neither Ach nor the Ach agonist, carbachol, induced changes in the length of the OHCs isolated. Therefore, our results with both agents are consistent and suggest alternate interpretations for the changes found by others (Brownell et al, 1985; Slepecky et al, 1988b; Plinkert and Zenner, 1989).

Of additional interest are the effects of efferent neurotransmitter substances other than Ach on the length of isolated OHCs. Although Ach is the transmitter of the majority of the efferent neurons innervating the cochlea, a subpopulation of efferents may utilize GABA as a transmitter (see reviews by: Altschuler and Fex, 1986; Bledsoe et al., 1988). GABA-containing efferent nerve fibers are localized mostly in a small population of efferent neurons innervating the OHCs of the third and 
first half of the fourth turns in the mammalian cochlea (Fex and Altschuler, 1984; Altschuler and Fex, 1986; Fex et al., 1986; Eybalin, et al., 1988). Also, some OHCs appear to be innervated by both GABA and Ach containing efferents (Altschuler and Fex, 1986). Although GABA is a major neurotransmitter in the vertebrate central nervous system, its role in synaptic processes of octavolateralis sensory organs is unresolved. Affecting $\mathrm{OHC}$ motility could be a role for GABA. However, we could not detect a change in the length of isolated $\mathrm{OHCs}$ to the application of GABA.

To date there are no reports of in vivo recordings from $\mathrm{OHCs}$ and their responses to efferent stimulation. Therefore, we do not know what properties of the OHCs are changed by the efferents. One possibility is that the efferent neurotransmitter(s) changes a cell constituent (e.g., cyclic AMP, inositol triphosphate) without shortening or elongation of the hair cell. On the other hand, indirect evidence suggests that the efferent neurotransmitter interacts with receptors on $\mathrm{OHCs}$, altering an ion channel and so induce a depolarization or hyperpolarization of the cell. For cochlear hair cells, Desmedt and Robertson (1975) suggest that the efferent neurotransmitter opens a chloride channel to allow chloride to enter the cell. For turtle hair cells (Art et al., 1982) and toadfish saccule hair cells (Steinacker and Rojas, 1988) it appears that the neurotransmitter opens a potassium channel and so allows potassium to leave the cell. Both ion fluxes would hyperpolarize the cell and presumably result in cell elongation. Flock and Russell (1973) recorded a hyperpolarization of the sensory hair cell of fish lateral line organ. On the other hand, it is possible that the efferent neurotransmitter acts on an ion channel which causes depolarization (e.g., calcium influx), resulting in cell shortening. In fact, Housley et al. (1990) find both depolarization and hyperpolarization responses to efferent transmitter application in the frog semicircular canal hair cells. In any case, as discussed earlier, if the efferent neurotransmitter depolarizes or hyperpolarizes the OHCs, the cell length would change, but the change in length would presumably be less than measured to date.

In summary, the literature has described many agents and treatments that alter the lengths of isolated $\mathrm{OHCs}$ by over $1 \mu \mathrm{m}$. Among them are changes in osmotic pressure, potassium concentration, and the efferent neurotransmitter, Ach. In our study, the cells did respond as expected to changes in osmotic pressure and potassium concentration. However, we were unable to detect a change in the lengths of the cells that could be attributed to the pharmacological actions of Ach, carbachol or GABA. We conclude that if Ach, carbachol or GABA did induce a length change it was less than $0.3 \mu \mathrm{m}$, the resolution of our methods.

\section{Acknowledgements}

Thanks to Robert Porter, Jr., Ph.D. for statistical help, Gail Ceasar and Jennifer Crist for technical help, James M. Brown, Ph.D. for writing the $\mathrm{OHC}$ measuring programs and Cindy Frazier for typing the manuscript. Supported by the Deafness Research Foundation, NIH research grants DC00379 and NS-05785, The Kresge Foundation, and the Louisiana Lions Eye Foundation.

\section{References}

Allen, J. B. (1988) Cochlear Signal processing. In: A.F. Jahn and J. Santos-Sacchi (Eds.), Physiology of the Ear, Raven Press, New York, pp. 243-270.

Ashmore, J. F. (1987) A fast motile response in guinea-pig outer hair cells: The cellular basis of the cochlear amplifier. J. Physiol. 388, 323-347.

Altschuler, R.A. and Fex, J. (1986) Efferent Neurotransmitters. In: R.A. Altschuler, R.P. Bobbin, and D.W. Hoffman (Eds.), Neurobiology of Hearing: The Cochlea, Raven Press, New York, pp. 383-396.

Art, J.J., Crawford, S.C., Fettiplace, R. and Fuchs, P.A. (1982) Efferent regulation of hair cells in the turtle cochlea. Proc. R. Soc. Lond. (B) 216, 377-384.

Bledsoe, S.C., Jr., Bobbin, R.P. and Puel, J.-L. (1988) Neurotransmission in the inner ear. In: A.F, Jahn and J.R. Santos-Sacchi (Eds.), Physiology of Hearing, Raven Press, pp. $385-406$.

Bobbin, R.P. and Kisiel, D.L. (1981) Physiology of hearing. In: R.D. Brown and E.A. Daigneault (Eds.), Pharmacology of Hearing, John Wiley \& Sons, New York, pp. 19-50.

Bobbin, R.P. and Konishi, T. (1974) Action of cholinergic and anticholinergic drugs at the crossed olivocochlear bundlehair cell junction. Acta Otolaryngol. (Stockh.) 77, 56-65.

Bobbin, R.P., Bledsoe, S.C., Jr., Winbery, S., Ceasar, G. and Jenison, G.L. (1985) Comparative actions of GABA and acetylcholine on the Xenopus laetis lateral line. Comp. Biochem. Physiol. 80C, 313-318. 
Brownell, W.E. (1983) Observations on a motile response in isolated outer hair cells. In: W. R. Webster and L. M. Aitken (Eds.), Mechanisms of Hearing, Monash University Press, Melbourne, pp. 5-10.

Brownell, W.F. (1984) Microscopic observation of cochlear hair cell motility. Scanning Electron Microscopy III, 14011406.

Brownell, W.E., Bader, C.R., Bertrand, D. and de Ribaupierre, Y. (1985) Evoked mechanical responses of isolated cochlear outer hair cells. Science 227, 194-196.

Dallos, P. (1985) The role of outer hair cells in cochlear function. In: M.J. Correia and A.A. Perachia (Eds.) Contemporary Sensory Neurobiology, Liss, New York, 207-230.

Davis. H. (1983) An active process in cochlear mechanics. Hear. Res. 9, 79-90.

Desmedt, I.F. and Robertson, D. (1975) Ionic mechanism of the efferent olivo-cochlear inhibition studied by cochlear perfusion in the cat. J. Physiol. (Lond.) 247, 407-428.

Dulon, D., Aran, J.-M. and Schacht, J. (1987) Osmotically induced motility of outer hair cells: Implications for Meniere's disease. Arch. Otorhinolaryngol. 244, 104-107.

Dulon, D., Aran, J.-M. and Schacht, J. (1988) Potassium-depolarization induces motility in isolated outer hair cells by an osmotic mechanism. Hear. Res. 32, 123-130.

Eybalin. M., Parnaud, C., Geffard, M. and Pujol, R. (1988) Immunoelectron microscopy identifies several types of GABA-containing efferent synapses in the guinea pig organ of Corti. Neuroscience 24, 29-38.

Fex. J. (1966) Efferent inhibition in the cochlea related to hair-ell de activity: Study of postsynaptic activity of the crossed olivocochlear fibres in the cat. J. Acoust. Soc. Am. 41, 666-675.

Fex, J. and Altschuler, R.A. (1984) Glutamic acid decarboxylase immunoreactivity of olivocochlear neurons in the organ of Corti of guinea pig and rat. Hear. Res. 15, 123-131.

Fex, J., Altschuler, R.A., Kachar, B., Wenthold, R.J. and Zempel, J.M. (1986) GABA visualized by immunocytochemistry in the guinea pig cochlea in axons and endings of efferent neurons. Brain Res. 366, 106 117.

Flock, A. and Russell, I.J. (1973) The post-synaptic action of efferent fibres in the lateral line organ of the burbot Lota. J. Physiol. 235, 591-605.

Goldstein, A.J. and Mizukoshi, O. (1967) Separation of the organ of corti into its component cells. Ann. Otol. Rhinol. Laryngol. 76, 414-427.

Holley, M. C. and Ashmore, J. F. (1988) On the mechanism of a high-frequency force generator in outer hair cells isolated from the guinea pig cochlea. Proc. R. Soc. Lond. (B) 232 , $413-429$.

Housley, G.D., Norris, C.H. and Guth, P.S. (1990) Cholinergically-induced changes in outward currents in hair cells isolated from the semicircular canal of the frog. Hear. Res. $43,121-134$.

Iwasa, K. and Kachar, B. (1989) Fast in vitro movement of outer hair cells in an external clectric ficld: Effect of digitonin, a membrane permeabilizing agent. Hear. Res. 40 . $247-254$.

Kachar, B., Brownell, W.E., Altschuler, R. and Fex, J. (1986) Electrokinetic shape changes of cochlear outer hair cells. Nature $322,365-368$.
Kim, D. O. (1986) Active and nonlinear cochlear biomechanics and the role of outer-hair-cell subsystem in the mammalian auditory system. Hear. Res. 22, $105-114$.

Konishi. T. and Slepian, J. Z. (1971) Effects of the electrical stimulation of the crossed olivocochlear bundle on cochlear potentials recorded with intracochlear electrodes in guinea pig. J. Acoust. Soc. Am. 49, 1762-1769.

Mountain. D.C. (1986) Electromechanical properties of hair cells. In: R.A. Altschuler, R.P. Bobbin and D.W. Hoffman (Eds.), Neurobiology of Hearing: The Cochlea, Raven Press, New York, pp, 77-91.

Plinkert, P.K. and Zenner, H.P. (1989) Acetylcholine receptors in outer hair cells and their significance for cochlear biomechanics. Abstr. Assoc. Res. Otolaryngol. 409, P. 339.

Santos-Sacchi. J. and Dilger, J. P. (1988) Whole cell currents and mechanical responses of isolated outer hair cells. Hear. Res. 35, $143-150$.

Santos-Sacchi, J. (1989) Gadolinium ions reversibly block voltage dependent movements of isolated outer hair cells. Soc. Neurosci. Abstr. 15, 208

Schacht, J. and Zenner, H.P. (1987) Evidence that phospho-inositides mediate motility in cochlear outer hair cells. Hear. Res. 31, 155-160.

Slepecky, N., Ulfendahl, M. and Flock, A. (1988a) Effects of caffeine and tetracaine on outer hair cell shortening suggest intracellular calcium involvement. Hear. Res. 32, 11-22.

Slepecky. N.. Ulfendahl. M. and Flock, A. (1988b) Shortening and elongation of isolated outer hair cells in response to application of potassium gluconate, acetylcholine and cationized ferritin. Hear. Res. 34, 119-126.

Steinacker, A. and Rojas, L. (1988) Acetylcholine modulated potassium channel in the hair cell of the toadfish saccule. Hear. Res. 35, 265-270.

Wiederhold, M.L. (1986) Physiology of the olivocochlear system. In: R.A. Altschuler, R.P. Bobbin and D.W. Hoffman (Eds), Neurobiology of hearing: The cochlea, Raven Press. New York. pp. 349-370.

Zajic, G. and Schacht, J. (1987) Comparison of isolated outer hair cells from five mammalian species. Hear. Res. 26. $249-256$

Zenner, H.P. (1986a) Motile responses in outer hair cells. Hear. Res. $22,83 \ldots 90$

Zenner, H.P. (1986b) K+-induced motility and depolarization of cochlear hair cells: Direct evidence for a new pathophysiological mechanism in Meniere's disease. Arch. Otorhinolaryngol. 243, 108-111.

Zenner, H.P. (1988) Motility of outer hair cells as an active, actin-mediated process. Acta Otolaryngol (Stockh) 105. 39 44.

Zenner, H.P., Gitter, A., Zimmerman, U., Schmitt, U. and Fromter, E. (1985a) Die isolierte, lebende Haarzelle-Ein neues Modell zur Untersuchung der Horfunktion. Laryngol. Rhinol. Otol. 64, 642-648.

Zenner, H.P., Zimmermann, R, and Gitter, A.H. (1988) Active movements of the cuticular plate induce sensory hair motion in mammalian outer hair cells. Hear. Res. 34, 233-240.

Zenner, H.P., Zimmerman, U. and Schmitt, U. (1985b) Reversible contraction of mammalian cochlear hair cells. Hear. Res. 18, 127-133. 